Article

\title{
French Media Representations towards Sustainability: Education and Information through Mythical-Religious References
}

\author{
Tudor Mihaela Alexandra *(1) and Bratosin Stefan \\ CORHIS-Iarsic, Paul Valéry University Montpellier 3, Montpellier 34199 Cedex 5, France; \\ stefan.bratosin@univ-montp3.fr or sbratosin.univ.montp3@gmail.com \\ * Correspondence: mihaela.tudor@univ-montp3.fr or mihaela.tudor.com@gmail.com
}

Received: 2 February 2020; Accepted: 5 March 2020; Published: 9 March 2020

\begin{abstract}
The present article aims to analyze the representations and the role of symbolic forms of mythical-religious thought in the mediatization of sustainability. A main corpus of items, composed of the media information and news offer covered by the mainstream French media, and a secondary corpus, as important, related to Francophone scientific articles, was considered. The study, conducted on French media news referenced by the Google search engine between 2009 and 2018, highlights a production of secular meaning of sustainability through mythical-religious references, a growth in the spiritualization of media content of the journalistic offer on sustainability, and the hegemony of the media, the omnipotence of the mediatized thing producing "an effect of Church" by legitimizing a certain "truth" of the information.
\end{abstract}

Keywords: climate change; sustainability; religion; French mediatization; education and information; symbolic forms

\section{Introduction}

In the context of the debate on climate change and sustainability transition, this article aims to analyze the representations and the role of symbolic forms of mythical-religious thought in the mediatization of sustainability. According to the philosopher Ernst Cassirer [1], symbolic forms are processes of dynamic symbolization. Therefore, as expressions of culture, symbolic forms are cultural forms which act by (re)structuring the "structures" of reality in whatever fields of action they are to be found. They can be encoded and decoded in various ways, bearing specific symbolic functions [2]. For example, the myth itself is a symbolic form which constructs "a sensitive metaphorization of reality", or even, a phenomenal revelation of life's subjectivity. In contrast to scientific thinking, mythical-religious thinking is a non-conceptual thinking, devoid of a critical dimension. It is a symbolic construction of meaning based on the objectivity of intuitive rationality $[1,3]$.

In our analytic model, we considered two corpora: a main corpus of items composed of the media information and news offer covered by the mainstream French media and a secondary corpus, as important, related to Francophone scientific articles during the period 2009-2018. The two corpora were referenced by the search engine Google and Google Scholar, respectively.

The notion of sustainability conquered the French media in the second half of the 20th century. Generally, it has penetrated news content by raising questions related to the environment, the economy, or society. Its use was already detected at the beginning of the 1960s in the press articles, such as the articles by Marc-Ambroise from the "Aménagement du territoire", section of the newspaper Le Monde, or broadcasts, such as the television program by Michel Péricard, "La France défigurée", presented by Louis Bériot and launched in 1971, on the militant background of the professionalization 
of environmental journalism [4,5]. The amplification and anchoring of the idea of sustainability in relation to environmental, economic, and social news then gave rise to scientific publications, such as [6-11], which follow the same issues as the media followed. Scientific publications exist in the wake of very extensive Anglophone literature oriented toward the promotion of sustainability in an environmental, economic, and social context, which calls for general awareness by proposing various actions under the sign of urgency [12-33]. The pragmatism of this academic promotion of sustainability is based on the establishment of specific indicators for the hard and social sciences [34-39].

Henceforth, the universal urgency of a global intervention solicits the contribution of the cultural sciences [15,40-56]. Academic and media discourses have started to focus on the problem of the relationship between sustainability and religion in the broad sense of spirituality in its various forms and cultural declinations. One of the salient illustrations of the resurgence of this perspective in the academic field is the Forum on Religion and Ecology at Yale University, whose objective "is to create a new academic field of study that has implications for environmental policy and environmental humanities" [57]. At the origin of this project were a memorable series of conferences organized between 1996 and1998 at Harvard's Center for the Study of World Religions with the participation of over 800 environmentalists and international scholars of the world's religions (Buddhism, Confucianism, Shinto, Hinduism, indigenous traditions, Judaism, Christianity, Islam, Taoism, Jainism, etc.). However, policy-oriented evangelical environmentalism will bring the issue of the relation between sustainability and religion into the public media sphere [43].

Contrary to previous observations, the impact of religion on sustainability is perceived as not only positive, but also, and above all, as performative [8,58-64]. By considering this theoretical contextualization that is inscribed in the very history of the concept of sustainability, we aim to highlight how sustainability is linked to religion in the mediatization of news in France, specific to a public sphere trapped in the ambiguous political implementation of a secularism whose meaning is constantly blurred by the media according to the conventions and ideologies at work [65-67].

The paper is structured as follows: theoretical background and empirical-methodological delimitations, presentation of the findings, and discussions and conclusion.

\section{Theoretical Background}

The global phenomenon of the "media staging" of news is a current issue in theoretical and empirical studies, which propose and operationalize the mediatization not only as a new concept but also as a new paradigm of interpretation and understanding of current societies [68-91]. Generally, research on mediatization reveals two major theoretical frameworks: a) an institutionalist framework, which focuses on the adaptation of various systems and domains (social, political, religious, cultural, etc.) to the logic of media institutions [74-79] and b) a more complex social, constructivist framework, which approaches this concept as a process of the communicative construction of sociocultural reality [78]. Both frameworks converge on the thesis that mediatization is an expedient instrument for analyzing critically "the interrelation between changes in media and communications on the one hand and changes in culture and society on the other" [74] (p. 196), and, as such, they are particularly relevant for the study of sustainability. Mediatization reflects how the consequences of multiple processes of mediation shape the understanding of the dimensions of a society-in this case sustainability. In this respect, the concept refers to a process of profound transformation of the media system - the media being dissolved completely and invisibly throughout society $[72,92,93]$. They create a "media-life" [94] and become a meta-process analogous to globalization, democratization, urbanization, commercialization, or individualization [84].

Winfried Schulz [95] establishes four dimensions of mediatization: (1) the extension of human capacities for communication through time and space, (2) the substitution of prior or direct social activities or experiences with mediated ones, (3) the fusion of interpersonal and mass-mediated activities, and (4) the adaptation of social activities and institutions to the media logic. By considering these dimensions and the sensitizing value of this paradigm, which "offers a general sense of reference 
and guidance in approaching empirical instances" $[89,96]$ (p.464), we will attempt to demonstrate how sustainability can be productively reinterpreted in terms of mediatization.

The media approach to news on sustainability induces in the French public sphere a particular tension that articulates the coexistence of religion and sustainability. It participates in the mediatization of culture. Culture embeds not only the news or the products of the media of popular culture. It encompasses language, traditions, practices, artistic achievements, community rituals, religions, and many other specific elements associated with a territory. Likewise, the mediatization of the news becomes a part of the mediatization of religion, as the operationality of faith is not limited to the religious sphere. For instance, faith operates alongside scientific facts in scientific activity [97] or in economic transactions. Faith and the sacred in general are present in the media (churches, religious, or spiritual events, etc.), elements of religion are present in the media of popular culture $[98,99]$, and the media itself operates according to the logic of religion. More precisely, the media embodies a symbolic power, previously represented by the clergy, arrogating to itself the same status and the same prerogatives, although secular, but no less dominant and exclusive [100].

The mediatization of culture becomes a culture of mediatization in its own respect, whose main resources are mediated by media technology. Therefore, everyday life in the culture of mediatization is "reshaped" by the existing media [78]. The mediatization of culture cannot be reduced to the simple fact that such or such media takes hold of a cultural reality, such as for example religion, to deal with sustainability. From this perspective, our approach takes into account the fact that "mediatization covers two simultaneous and dialectical movements. On the one hand, it is the result and consequence of relations, interrelationships, connections, and interconnections of the use by society of communication means and tools enhanced by digital technology. On the other hand, it means a new social environment that focuses deeply on those relations, interrelationships, connections, and interconnections that build a contemporary society. The society is in mediatization. The human being is in mediatization. It must be underscored that such an idea of mediatization configures a new way of being in the world" [76] (p.201).

Therefore, we consider that whatever the comprehensive framework at work in the media information offer is, the meaning of news mediatization is dependent on two paradoxical trans-paradigmatic fluid constants: a) the fact of informing, i.e., to stage the visible and the expressible and $b$ ) the fact of insinuating, that is to say to stage the invisible and the non-expressible.

Thenceforth, we will highlight the paradoxical production of meaning of news mediatization which, accommodating religion and sustainability, engages factual information and ideological justification, human rights and mythical-religious thought, rational distance and emotional proximity.

\section{Method and Corpus}

Anchored into an exploratory research design, this study aimed to state and test hypotheses intended to establish potential causal relationships between variables derived from secondary sources, organized in three clusters, such as:

a) literature review;

b) digital methods. In order to collect digital traces asynchronously, we mined data from search engines that operate on information stored in their own digital environment. Even if this procedure raises a set of unavoidable methodological challenges, they nevertheless allowed access to information and data that is difficult to capture with the traditional methods confer [101];

c) discourse analysis- used to capture the discourses used, the relationships and the affinities that they develop, along with their consequential representations.

The analysis mainly concerned a corpus of news disseminated by the French mainstream media between 2009 and 2018. There were 32 media according to the following categories: national daily newspapers (e.g., Le Monde, Le Figaro, La Croix, Libération, Marianne, etc.), daily regional press (e.g., Var et Nice Matin, Midi Libre, Le Parisien, La Voix du Nord, etc.), magazines (e.g., L'Express, Le Nouvel Observateur, Paris Match, etc.), media on social networks (e.g., Brut on Facebook), and press agency 
(e.g., Agence France Press - AFP). Secondly, a corpus of Francophone scientific articles, all domains combined, was constituted for the same period in order 1) to highlight the imbalance between the media interest and the scientific interest for the coupling of sustainability and religion and 2) to show how and why media treatment is captive to a mythical-religious thought.

The corpora gathered the articles/items referenced by the search engine Google (media articles) and Google Scholar (scientific articles). In order to measure the presence and evolution of religious references within the media information offer on sustainability, we identified and took into account a total of 2915 news items on sustainability produced between 2009 and 2018 by all the French mainstream media, including 2007 news items focusing on the sustainability-religion tandem. In the same period, we identified 96,610 scientific articles on sustainability, including 8511 articles on the sustainability-religion tandem. Data collection was made based on research using a protocol of relevant keywords, implemented from a documentary study of the literature (see references in the introduction section), focused mainly on the combination of "sustainability and religion" and their specific declinations, such as "apocalypse", "Buddhism", "Confucianism", "Shinto", "Hinduism", "indigenous", “tradition", “Judaism", “Christianity", “Islam", "Taoism", “Jainism”, “evangelism”, "faith", "Bible", "God", "sacred", "religion", "church", "pray", "worship" ...

Our methodology was built on the theoretical model developed by Fairclough [102,103], and it focused on discourse analysis at the interpretative level, with a particular emphasis on discursive practices and representations built on sociocultural (religious) resources contained in the press articles. Discourse analysis acknowledges that the relationship between the use of language and non-discursive reality is dialectical [104]. Therefore, it is central to the understanding of discourse as a representation, and as a way of transforming reality [95]. In this context, we scrutinized media article excerpts in order to determine the sociocultural representations of religious-oriented sustainability. Two types of discourse emerged as a result. The discourse of "scientific language", with references to science and the discourse of "religious language" with references to mythical-religious thought, which constituted our focal point. Our study was structured into two parts. Part one measured the evolution of religious references in the media on sustainability, and part two identified the sociocultural religious representations used by the media in establishing a link between sustainability and religion in the presentation of news media.

\section{Findings}

The results of the two parts presented (1) the evolution of religious references in the media on sustainability and (2) the organic articulation in the French news media of sociocultural representations of sustainability and religion.

\subsection{Evolution of Religious References in the Media Information Offer on Sustainability}

From the news media corpus, $68.85 \%$ of items included references to religion (Figure 1). Only $8.80 \%$ of the scientific articles on sustainability referenced by Google Scholar included references to religion (Figure 2). The scientific articles on sustainability identified were not, however, the main subject of this research. We used them only as elements of comparison in order to highlight the meaning of the quantitative results concerning the corpus of news media on sustainability in relation to religious themes and references. 


\section{NEWS MEDIA CORPUS ON SUSTAINABILITY: REFERENCES TO RELIGION}

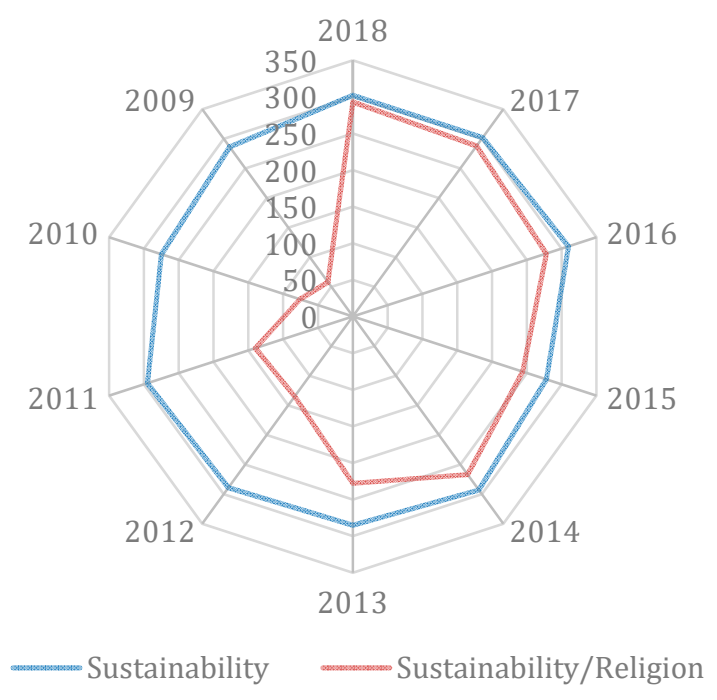

Figure 1. News media corpus on sustainability: references to religion.

\section{SCIENTIFIC ARTICLES ON SUSTAINABILITY: REFERENCES TO RELIGION}

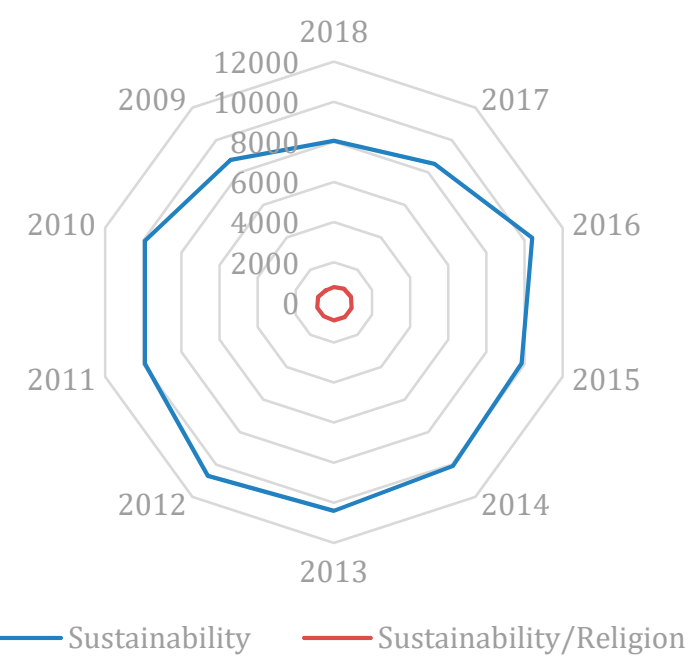

Figure 2. Scientific articles on sustainability: References to religion.

The annual evolution of the number of French news media items that use religious references in the treatment of sustainability topics shows that in the period 2009-2018 there was considerable growth. Thus, from $20.28 \%$ in 2009 , the number of French news media items using religious references when approaching sustainability issues rose to $97.01 \%$ in 2018, with peaks of growth in $2011(47.45 \%)$, in 2014 (91.12\%), and in 2018 (97.01\%) (Figure 3). At the same time, the growth concerning scientific articles was insignificant-from $8.17 \%$ in 2009 to $9.39 \%$ in 2018 with a more notable increase in 2011 (8.80\%), 2015 (9.40\%), and 2017 (9.87\%) (Figure 4). 


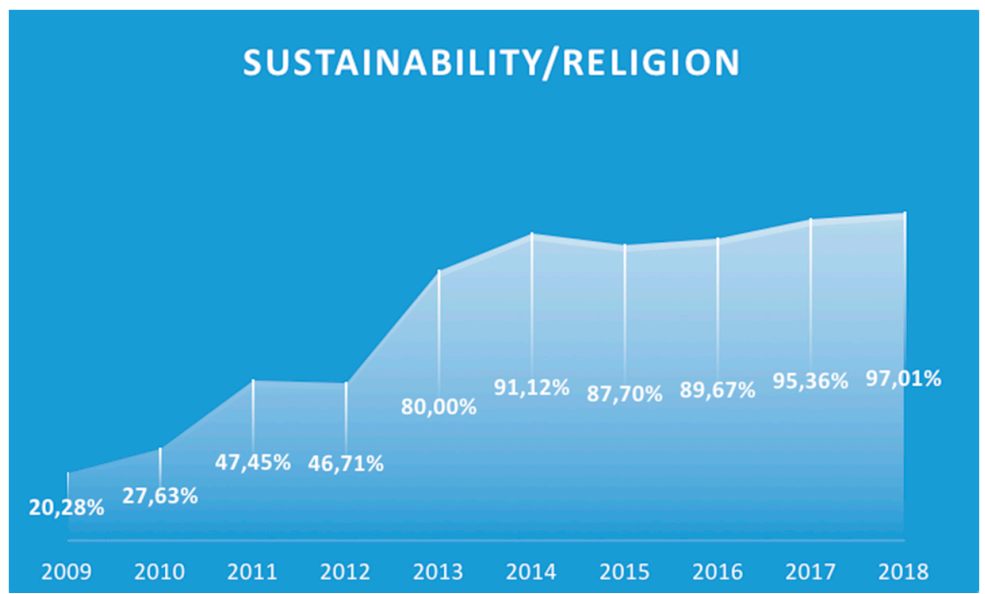

Figure 3. French news media items using religious references in the treatment of topics on sustainability.

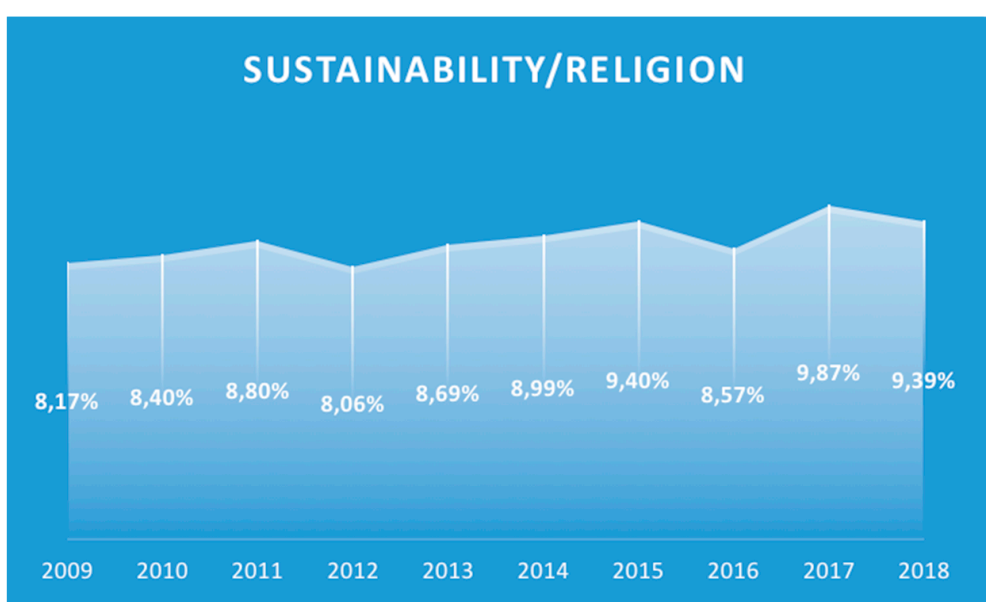

Figure 4. Francophone scientific articles using religious references in the treatment of topics on sustainability.

In the period 2009-2018 the gap between the number of articles in French news media and the number of Francophone scientific articles using religious references when approaching sustainability topics increased from $12.11 \%$ in 2009 to $87.62 \%$ in 2018 (Figure 5).

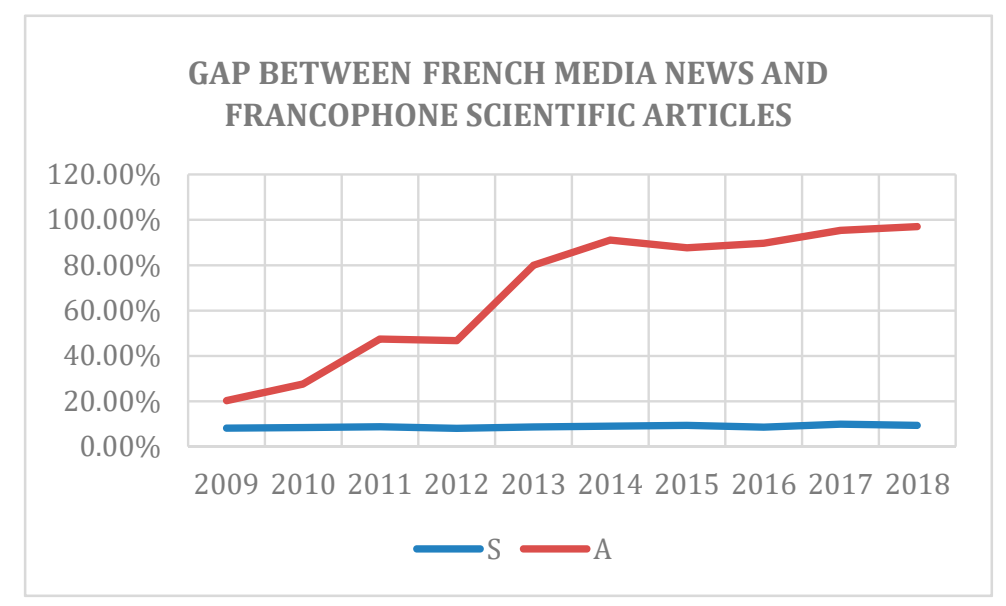

Figure 5. Gap between the number of articles in the French news media and Francophone scientific articles which used religious references. 


\subsection{Sustainability and Religion in French News Media: Sociocultural Representations}

The media treatment of French current issues on sustainability brings together three categories of sociocultural religious representations: a) the founding representations of the mediatization of sustainability, b) dogmatic representations of the mediatization of sustainability, and c) pragmatic representations of the mediatization of sustainability.

\subsubsection{Founding Symbolic Representations: The Mediatization of Paradise and the Apocalypse}

The founding representations of the notion of sustainability in the media are constructed with mythical-religious material provided by the collective imaginary in relation to a lost paradise and frightening information based on apocalyptic scenarios. Thus, the media portrayal of sustainability as a means of achieving a rediscovered paradise conveys an enormous palette of representations that cover all aspects of human life and environment, such as the "plan of action for people, planet, and prosperity" of "Transforming our World: the 2030 Agenda for Sustainable Development", published in 2015 by United Nations.

The circulation of these representations superimposes three layers of meaning:

a) Firstly, the meaning induced by the media: "They help to fix the ways of thinking, in large part determining ideas, habits, and customs. They are (... ) in a way the judges of the truth, they decide and dictate the ways of life. They establish what is wrong, and decide what are the important and significant events" [105];

b) Secondly, the ideological meaning of reconstructing an optimistic vision of the future, taking up a loss of the past, a vision in opposition to an unpleasant present dominated by negative information. This is about using the references of sustainability to mobilize the imaginary of a pragmatist, which could bring out a collective faith in a future restoration of human existence and its framework of development;

c) Thirdly, the pragmatic meaning of the commodification of current individual freedoms against the necessary happiness of security of future daily life. French mainstream media portray the apocalypse using emotions that precede and blur the general manifestation of critical thinking. This mediatization is characterized by the articulation of three media acts: (a) the reduction of discursive polyphony to a discourse taken up in unison, (b) the management of the shortage of factual information, and (c) the construction of a secular theology of sustainability as in the following example: "In 2003, Olafur Eliasson staged an amazing artificial twilight within Tate Modern ( ... ) hordes of dumb visitors came to contemplate this end of the world full of grace ( ... ) It was light years away from the big bang Instagram; a selfie, they barely knew what it was. Sixteen years after this landmark Weather Project, science fiction has almost come true. The climatic apocalypse, which for a long time was only a fantasy for which artists could make their honey, is now fast approaching. It is not at Eliasson, a great environmental activist before the Lord, that we will hear the sad news. No more illusion: the time is now for action, as desperate as it is [24]". Or "The apocalypse clock is not a science fiction concept: very real, it symbolizes the imminence of a cataclysm on a planetary scale, midnight representing the end of the world. Each year, the bulletin of atom scientists, an American NGO which brings together researchers and experts in the field of nuclear disarmament and climate change, including 15 Nobel Prize winners, gathers to decide whether to advance or delay the deadline. Verdict for 2018? 30 seconds less before the end of the world compared to 2017, which brings the time to 2 minutes before midnight. In question? The increased risk of global nuclear conflict and the 'unpredictability' of US President Donald Trump. Beyond the atomic risk, there is also the question of climatic risk" [106].

Representations of paradise and the apocalypse in the French news media on sustainability are grouped around seven major items - health, food, transport, housing, education, climate, and social justice. By considering these items, we listed 356 occurrences in our corpus corresponding to representations of "lost paradise" and 682 occurrences corresponding to "apocalyptic representations". Across all these occurrences, the thematic connection of the founding symbolic representations varied between $31 \%$ for "climate" and $5 \%$ for "transport". The themes of "health" and "food" included, 
respectively, $22 \%$ and $19 \%$ of occurrences. Finally, the theme of "social justice" generated $9 \%$ of occurrences and the themes of "housing" and "education" each 7\% (Figure 6).

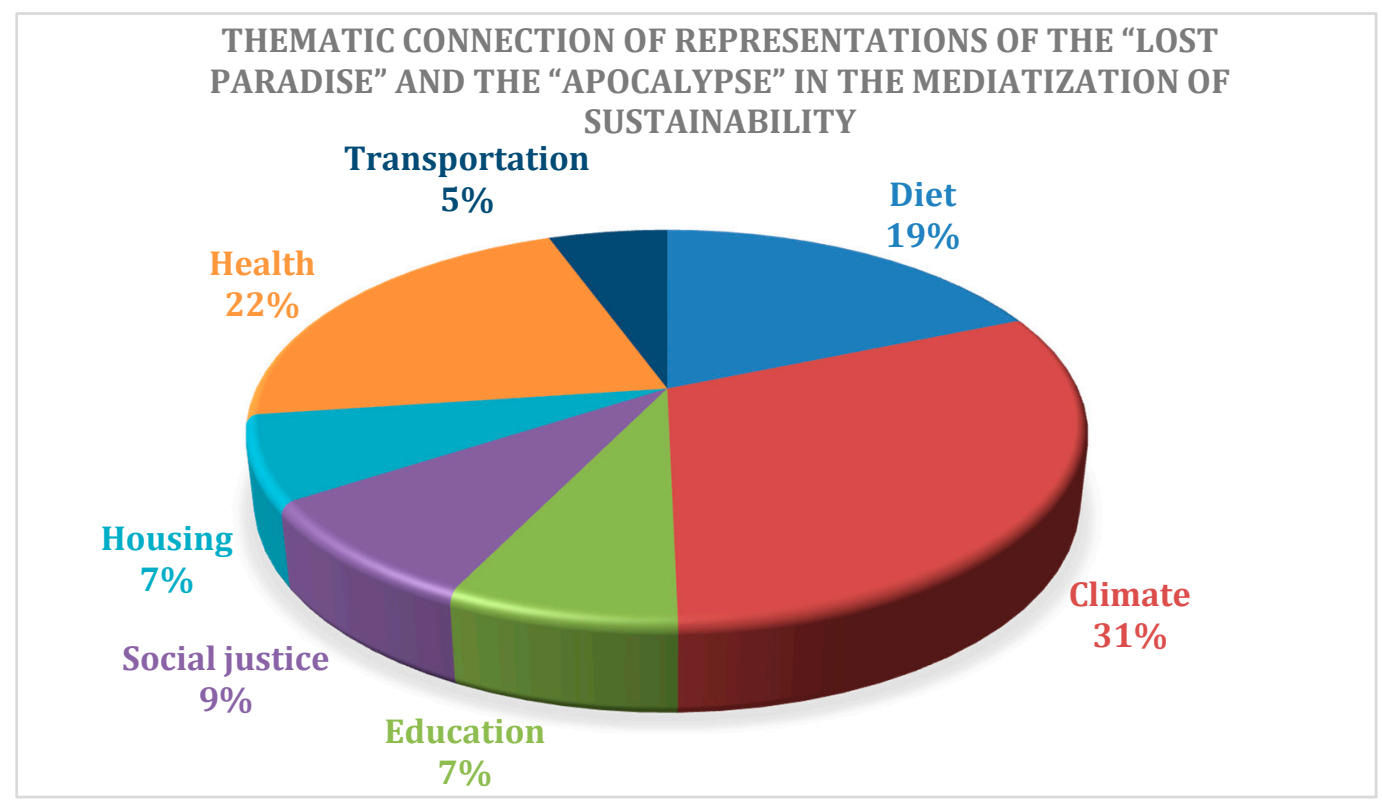

Figure 6. Thematic connection of representations of the "lost paradise" and the "apocalypse" in the mediatization of sustainability.

The content of these representations was nevertheless different for each item. For example, even if the items "housing" and "education" each had 7\% of occurrences, the content of the occurrences of "housing" was dominated by the representations of the "lost paradise", while the content of occurrences of "transport", the representations of "lost paradise", and of the "apocalypse" had almost equal positions (Figure 7).

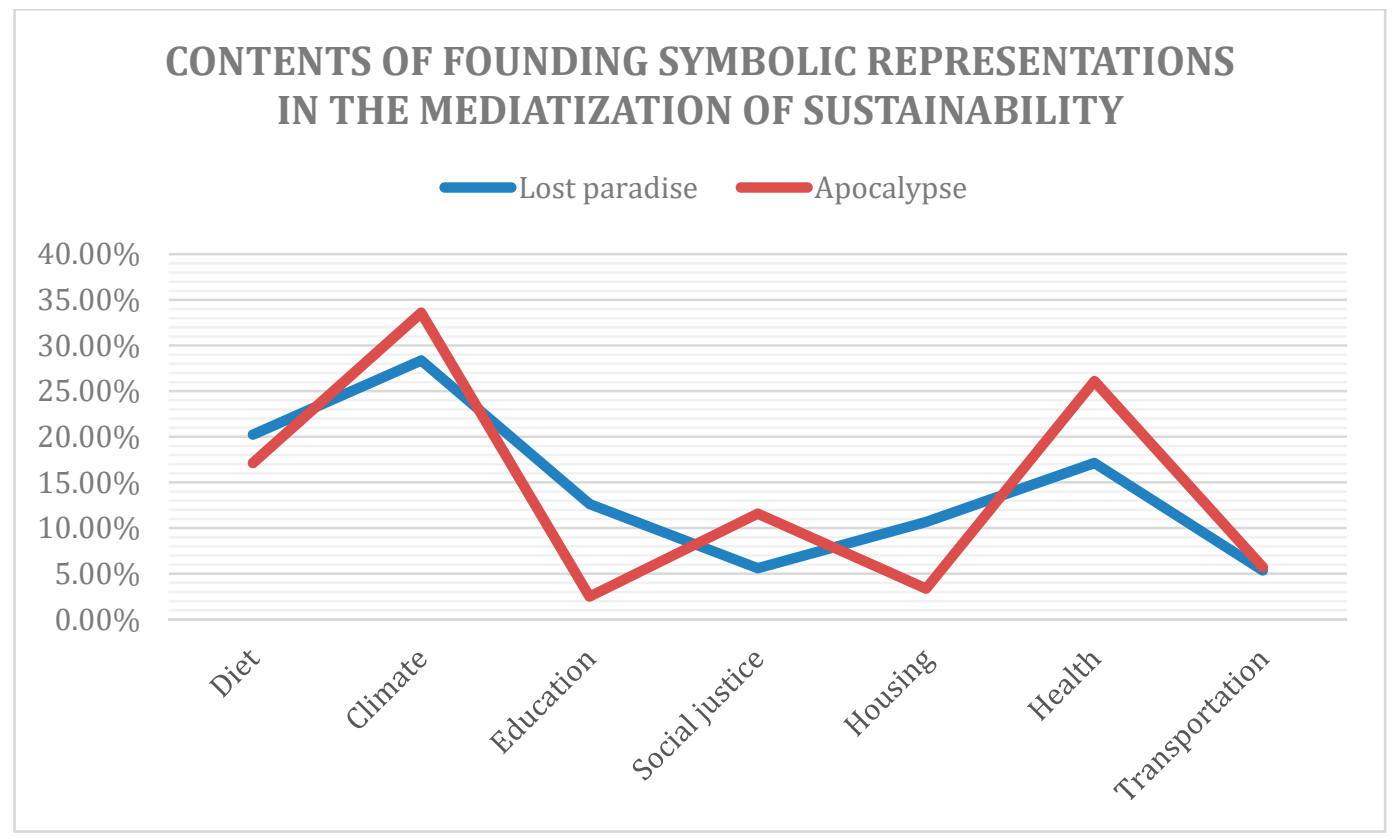

Figure 7. Contents of founding symbolic representations in the mediatization of sustainability. 


\subsubsection{Dogmatic Representations: The Mediatization of Promises and Hope}

Another category of sociocultural religious representations of sustainability are the "classic" dogmatic representations that project various promises and messages of hope echoing the objectives of the United Nations [107] — no poverty in all its forms anywhere; zero hunger; food security and improved nutrition; healthy lives and the promotion of well-being for all at all ages; inclusive and equitable quality education and the promotion of lifelong learning opportunities for all; gender equality and the empowerment of all women and girls; the availability and management of water and sanitation for all; access to affordable, reliable, sustainable, and modern energy for all; inclusive economic growth; full and productive employment and decent work for all; resilient infrastructure; the reduction of inequality within and among countries; making cities and human settlements inclusive, safe, and resilient; the combat of climate change and its impacts; conservation of the oceans, seas, marine resources, terrestrial ecosystems, and forests; peaceful and inclusive societies,; and access to justice for all, etc.

These media representations of sustainability are mainly related to the three "classic" dimensions of the concept. More precisely, they give meaning to sustainability in the spheres of economic, environmental, and social predictions through media discourse, such as for example "Investing your money responsibly means combining financial return and 'societal' return, also called 'extra financial' return. They are socially responsible investments and dedicate their funds to companies of an ethical, social, or environmental nature" [108]. Or "between the trade of animals for the production of wool, leather, and other furs, and the dyeing factories ravaging the surrounding water, the traditional fashion sector is doubly polluting. But the English designer proves that it is possible to make an ethical and sustainable luxury fashion. Organic cotton produced with the minimum of water, synthetic leather which skates over time like a classic skin, and fake fur more real than nature: as she has known how to do for fifteen years for women, Stella McCartney should soon rhyme eco-responsible and desirable fashion for men" [109].

We identified 483 occurrences in our corpus that we matched with representations of "promises" and 359 occurrences corresponding to representations of "hope". The connection of these representations to the "environment" item in the media treatment of sustainability was dominant, at $68 \%$, compared to the "economy" and "society" items, whose connections were $18 \%$ and $14 \%$, respectively (Figure 8). For "environment", a balance between "promises" and "hope" characterized the content of dogmatic representations. Differently, for "economy" the content of these representations was dominated by occurrences of "promises", while for "society" the dominant occurrences were those of "hope" (Figure 9). 


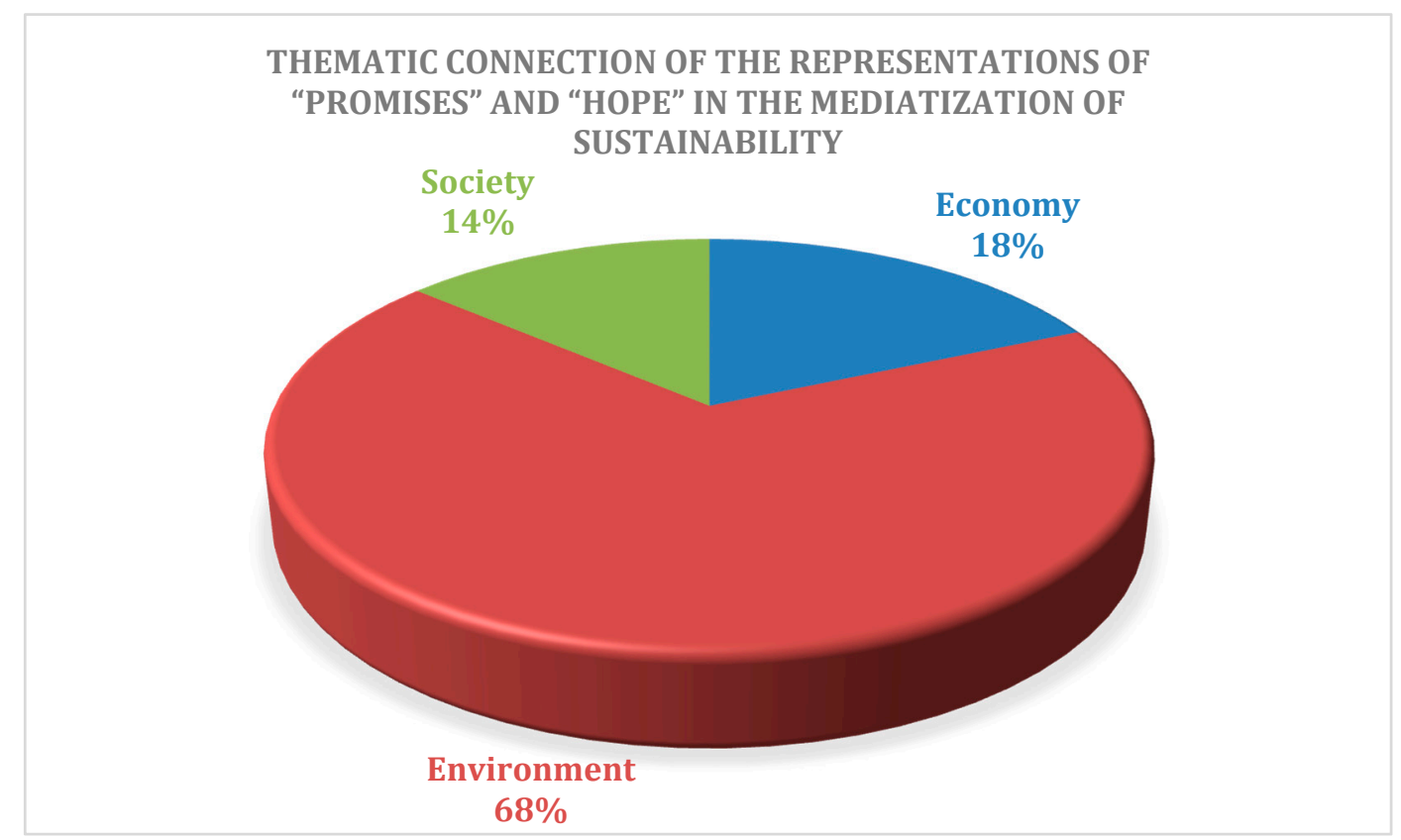

Figure 8. Thematic connection of the representations of "promises" and "hope" in the mediatization of sustainability.

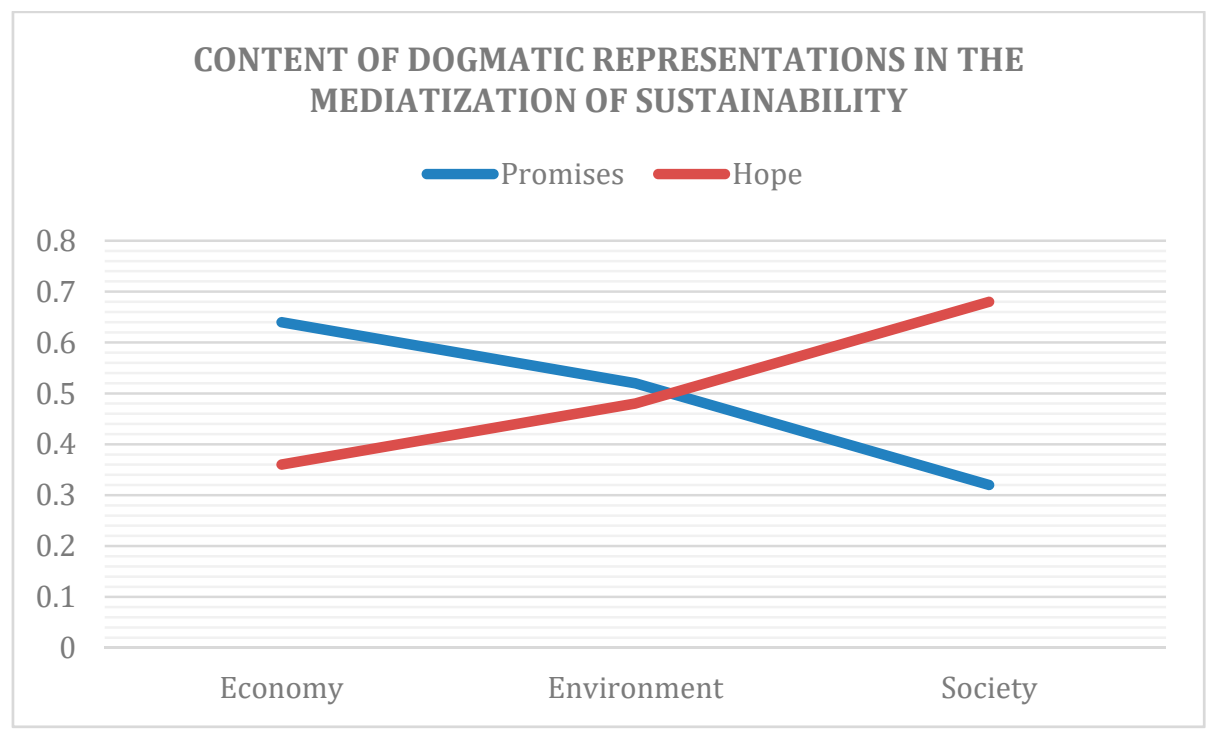

Figure 9. Content of dogmatic representations in the mediatization of sustainability.

\subsubsection{Pragmatic Representations: The Mediatization of Love, Sharing, and Temperance}

Pragmatic representations result from an intellectual articulation between belief and experience. In this articulation, the mediated sustainability was based on religious representations of belief, because belief "is something of which we are aware; then it soothes the irritation caused by doubt; finally, it implies the establishment in our mind of a rule of conduct" [110] (p. 45). Belief appears, for the religious mediatization of sustainability, as one of the best paradigms of meaning. The role of this paradigm is increased by the fact that experience religiously responds to conditions that "include the need to establish and maintain the balance of an organism with an environment as well as the pursuit of different kinds of aims and interests" [111] (p. 124). These representations are in fact figures in action of knowledge by action. Three of them stand out significantly-love, sharing, and temperance. These figures are often articulated in the mediatized subject- "After the 'bobos' and the 'nimby', 
the ecological sphere welcomes a new trend: the 'ginks', like 'Green inclined, no kids'." Launched by the American Lisa Hymas on her childfreefeminist blog, this trend could have a strong impact with the release of the book by Stefanie Iris Weiss, columnist at the Huffington Post. In Eco-Sex: Go Green Between the Sheets and Make your Love Life Sustainable, she explains why women have an interest in not procreating for the good of the planet" [112]. Or "Don't throw it away, the yard is full: every year in France, each individual throws on average $29 \mathrm{~kg}$ of food that is still consumable, including 7 still packaged. (..) the cost is not only financial, it is also ethical and social (...) without speaking of the ravages on the environment ( ... ) Contribute to the reduction of waste in canteens while helping the most deprived: this is the bet of Excellents Excédents, $(\ldots)$ the founder, $(\ldots)$, consultant in sustainable development, ( ... ) embarks on its collection across the Paris region" [113].

We identified 279 occurrences concerning representations of "love", 481 occurrences regarding representations of "sharing", and 354 occurrences for representations of "temperance". These occurrences were mainly linked to three thematic items: a) "resources" 46\%, b) "production" and "consumption" 36\%, and c) "human development" 18\% (Figure 10). For each item, the representations' contents were dominated by different occurrences: (a) for the "resources" item, the occurrences of "love" were dominant, followed by "sharing" and "temperance"; (b) for the "production and consumption" items imposed, the occurrences of "sharing" followed by "temperance" and "love", and (c) for the "human development" item, the occurrences of "temperance" prevailed followed by "sharing" and "love" (Figure 11).

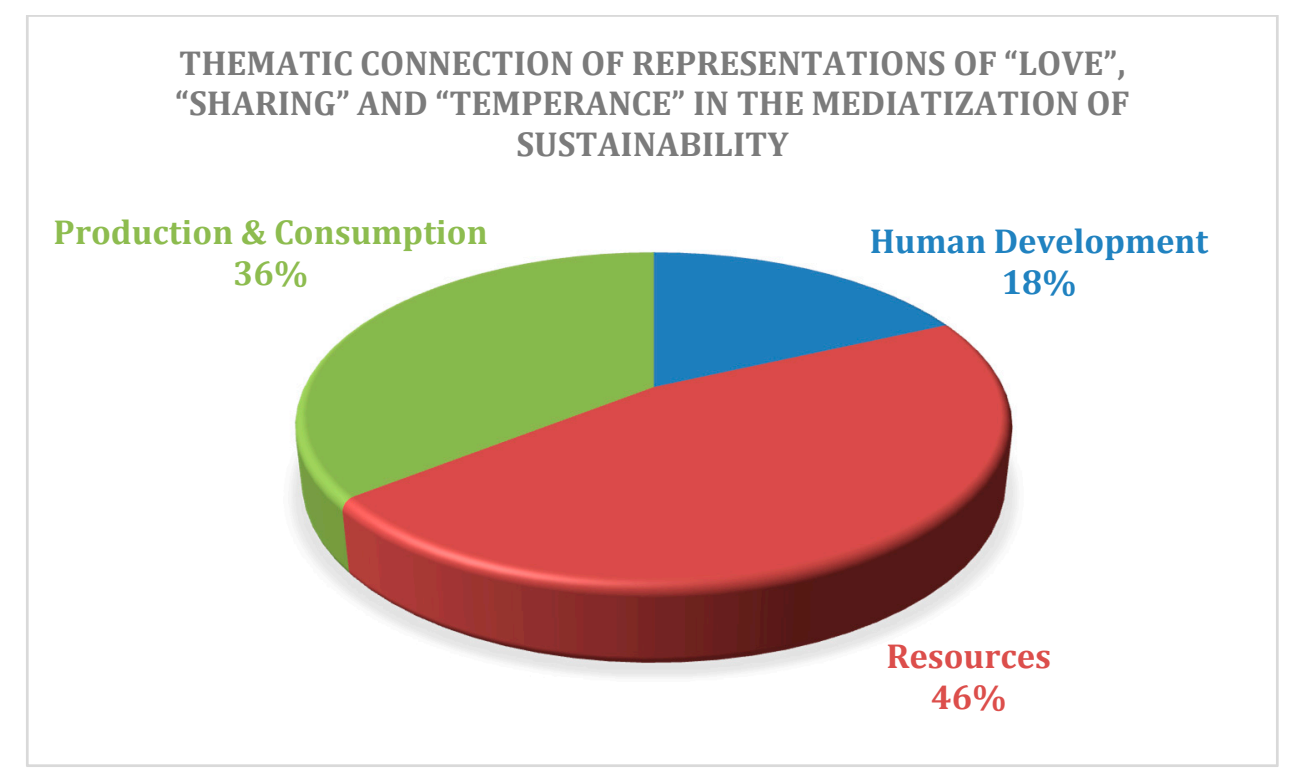

Figure 10. Thematic connection of representations of "love", "sharing", and "temperance" in the mediatization of sustainability. 


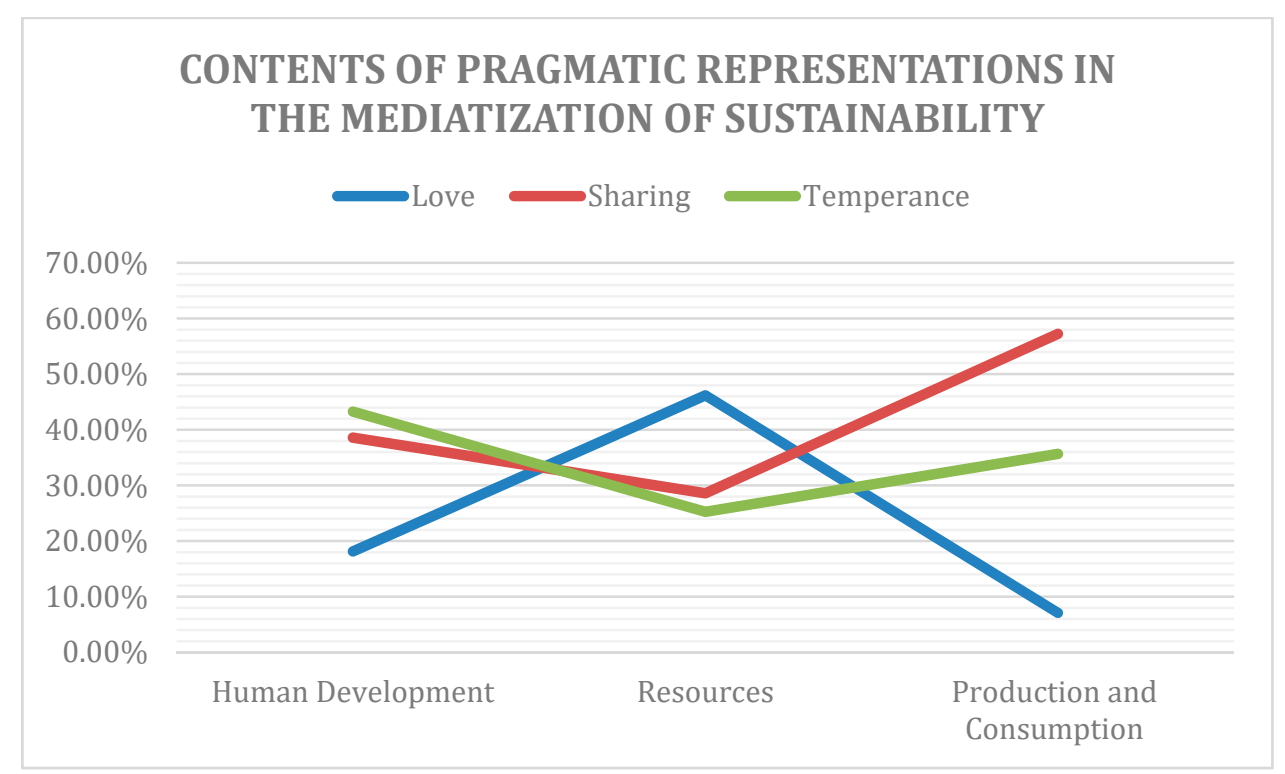

Figure 11. Contents of pragmatic representations in the mediatization of sustainability.

\section{Discussion}

Considering the findings, we observed a high degree of representation of religious references regarding sustainability in the French mainstream media compared to a low representation of this type of reference in the scientific production. This discrepancy indicates a media approach to sustainability in the French public sphere in two different registers: one that aims primarily at emotional experience and affective knowledge and another that aims at intellectual understanding and conceptual knowledge. In this respect, the French mediatization of sustainability through economic, social, political, and cultural news engages the representations of a spiritual environment provided in traditional symbols by the collective French imaginary, an environment which "naturally" echoes a religious ecology which "considers creation as a dynamic fabric of related processes. [ ... ] What is fundamental is not the 'elementary particles' [ ... ] but the harmony of the connections and movements which transcend themselves, in which the aspiration of the Spirit toward a perfection not yet achieved. If the Cosmic Spirit is the Spirit of God, the universe cannot be viewed as a closed system. It should be understood as an open system for God and his future" [114] (p.141). At this point, it is worth emphasizing that the mediated representations on sustainability are relevant to the debates in the field of scientific representations [115], as they try to reconcile the theory with the world; thus trying to bring answers on the ontology of the models as representations of parts or aspects of the world. The mediated representations reveal how the techniques of representation (in this case the media) participate both in the construction of objectivity (real value because of the explanation provided), as well as in the construction of subjectivity (lack of real value due to a lack of explanation), within the broader process of knowledge building.

News media on sustainability appear in the French media under the less and less camouflaged influence of mythical-religious thought [1], as "In places where sustainability provides convincing identity markers for people who use the term to reflect particular visions of where society is headed and what values it ought to maximize, it is fulfilling the function of explicitly religious narratives-a basic companion to human culture" [116] (p. 198). The secular character ostensibly claimed and attached to the French journalistic/media activity of information is neither an obstacle to associate the religious universe with the mediatization of sustainability nor an absolute novelty, because "even ostensibly secular international organizations utilize the religious dimensions of sustainability (in the form of spiritualized language, religious metaphors, or discourses of awe and reverence) for their own, often different ends" [116] (p. 55). 
A second result consists in the progression over time of the quantity of religious references in the French media information offer on current affairs. It is not a religious awakening that the media would echo, but a progression that corresponds to a growing French political and social interest in questions linked to the future of the planet. The fact that this growth is consistent with a constant increase in the volume of information on sustainability is proof of this, "the volume of media coverage can generally indicate the relative salience that is awarded to an issue over time in a given context (Mueller, 1973; Benton and Frazier, 1976; Naisbitt, 1976; Beniger, 1978; Dearing and Rogers, 1996; França Filho, 2005). Hence, measuring media salience by the volume or frequency of media coverage has emerged as a relatively common method in agenda-setting research (Funkhauser, 1973; Benton and Frazier, 1976; Howlett, 1997), as critiqued by Kiousis (2004). Examples in the context of sustainability include the coverage of EU environmental policies (Bijsmans and Altides, 2007), climate change (Brossard et al., 2004; Boykoff, 2007), or HIV/AIDS (Dearing, 1989)" [117] (p. 3). This growth can be, at the same time, the indicator of an unconscious recognition of the ontological need of the human being to have a spiritual reference even if it declines any religious attachment. In this perspective, sustainability presents to consciousness not as a need to be satisfied in the different areas of human activity, but as the daily experience of a moral experience imposed and ritualized by a secular trans-ideological spirituality $[118,119]$.

The third important result is the thematic connection of representations with religious connotations. Thus, the French media attach sustainability to religious representations indicating a) mythical limits_-"paradise" and "apocalypse" — which distinguish creation having a beginning and an end from its creator, who is out of time, b) religious means-"promises" and "hope"-which condition the imaginary as a motivational foundation in the management of the past and future, and c) spiritual strategies in the experience of present news. The contextual meaning of these thematic connections certainly does not indicate any media conversion, but the pre-eminence of an economic pragmatism in the production of news media. More precisely, the French media attach sustainability to religious representations because they are fertile in narratives that generate fusional behaviors by virtue of their inherently strong emotional charge [98].

Finally, a fourth result to consider is the religious content of the different representations in the media treatment of sustainability. This type of mediatization is an indicator of the historical cultural role played by sustainability in the secularization of the world's major religions. It responds to the spiritual quest for a "connected" world without limits or places, while participating in the secularization of a humanity which wishes to free itself from the constraints imposed for centuries by religious organizations and institutions [120]. These religious contents of the representation of sustainability highlight a loss of recognition of science in the collective conscience in favor of the "truth" of the media validated not by reason, but by the bodiless authority of mythical-religious "truth" concealed in the subconscious of its identity memory [3].

\section{Conclusions}

The outcomes of the research presented in this paper pinpoint three conclusive observations.

First, this study, conducted on the French news media, highlighted a production of secular meaning of sustainability through mythical-religious references. The novelty of the results is in resonance with the concept of mediatization, which does not limit the technological impact only to the increase in the speed and volume of information flows, but which also considers the capacity of new technologies of information and communication to transform the very content of sociopolitical and economic action.

Second, the two parts of the study show a growth in the spiritualization of the media content of the journalistic offer on sustainability in a context where the degree of credibility of the mainstream media is constantly decreasing and digital social media like Facebook are integrating within the mainstream media category. The study also shows the hegemony of the media, the omnipotence of the mediatized thing producing "an effect of Church" [100] (p. 50) and legitimizing a certain "truth" of information and a certain "reality". Media have the same function as that of institutionalized religion, a median position 
between morality, dogma, and prophetism [100,121]. Finally, media as a vessel, media as language, and media as environment [122] become the embodiment of the "truth", once owned by science.

Third, the specific impact of the French news media in the public sphere, along with the educational and informational meaning of the secular usage of mythical-religious references to communicate issues of sustainability, can be correlated with two major social trends observable in French society: a) the growing influence of the public sphere over the private sphere and b) the current incremental increase of public interest and political action to promote an inclusive culture.

Author Contributions: Conceptualization T.M.A. and B.S.; Methodology, T.M.A. and B.S.; Analysis and Discussion, T.M.A. and B.S.; Writing-original draft preparation, T.M.A. and B.S.; Writing-review and editing, T.M.A.; Supervision, T.M.A.; Project administration, T.M.A. All authors have read and agreed to the published version of the manuscript.

Funding: This research was funded by PHC Maghreb-Campus France (36902ZH) and Iarsic.

Conflicts of Interest: The authors declare no conflict of interest.

\section{References}

1. Cassirer, E. La Philosophie des formes symboliques. 2. La pensée mythique; Minuit: Paris, France, 1972.

2. Bratosin, S. La concertation. Forme symbolique de l'action collective; L'Harmattan: Paris, Paris, 2001.

3. Bratosin, S. La concertation. De la pratique au sens; Peter Lang: Berne, Germany, 2007.

4. Bodt, J.-M. La "Cite Ecologique" Dans L'espace Public Médiatique: Trajectoires De Controverses Environnementales Dans La Presse Generaliste Française, These De Doctorat; Université Toulouse-Jean Jaurès: Toulouse, France, 2014.

5. Comby, J. Quand l'environnement devient médiatique: Conditions et effets de l'institutionnalisation d'une spécialité journalistique. Réseaux 2009, 157-190. [CrossRef]

6. Gendron, C.; Revéret, J.-P. Le développement durable. Écon. Soc. 2000, 37, 111-124.

7. Godard, O. Le développement durable: Paysage intellectuel. Nat. Sci. Soc. 1994, 2, 309-322. [CrossRef]

8. Harper, F. Greening Faith: Turning Belief into Action for the Earth. Zygon@ 2011, 46, 957-971. [CrossRef]

9. Pearce, D. Economics, equity and sustainable development. Futures 1988, 20, 598-605. [CrossRef]

10. Zuindeau, B. Développement Durable et Territoire; Presses Univ. Septentrion: Paris, France, 2000.

11. Wilson, E.O. Biophilia; Harvard University Press: Cambridge, MA, USA, 1984.

12. Archibugi, F.; Nijkamp, P. Economy and ecology: Towards sustainable development; Springer: Berlin/Heidelberg, Germany, 1989.

13. Barbier, E.B. The concept of sustainable economic development. Environ. Conserv. 1987, 14, $101-110$. [CrossRef]

14. Bastianoni, S.; Porcelli, M.; Tiezzi, E. Sustainable development models for the analysis of the Province of Modena (Italy). WIT Trans. Ecol. Environ. 1970, 34, 89-95.

15. Brinkerhoff, D.W.; Goldsmith, A.A. Promoting the sustainability of development institutions: A framework for strategy. World Dev. 1992, 20, 369-383. [CrossRef]

16. Brown, D.R. Sustainability is not about money! The case of the Belize Chamber of Commerce and Industry'. Dev. Prac. 1997, 7, 185-189.

17. Clayton, A.; Radcliffe, N. Sustainability: A Systems Approach; Earthscan: London, UK, 1996.

18. Daly, H.E. Toward some operational principles of sustainable development. Ecol. Econ. 1990, 2, 1-6. [CrossRef]

19. Fama, E.F.; MacBeth, J.D. Risk, Return and Equilibrium: Empirical Tests. J. Political Econ. 1973, 81, 607-636. [CrossRef]

20. Fortune, J.; Hughes, J. Modern academic myths. In Systems for Sustainability: People, Organizations and Environments; Stowell, F.A., Ison, R.L., Armson, R., Holloway, J., Jackson, S., McRobb, S., Eds.; Plenum Press: New York, NY, USA; London, UK, 1997; pp. 125-130.

21. Frans, R. Sustainability of high-input cropping systems: The role of IPM. FAO Plant Protect. Bull. 1993, 41, 161-170.

22. Fresco, L.O.; Kroonenberg, S.B. Time and spatial scales in ecological sustainability. Land Use Policy 1992, 9, 155-168. [CrossRef]

23. Kheel, M. The Liberation of Nature: A Circular Affair. Environ. Ethics 1985, 7, 135-149. [CrossRef] 
24. Lequeux, E. Exposition: Olafur Eliasson fait son numéro d'urgence climatique. Available online: https:/www.lemonde.fr/culture/article/2019/08/16/exposition-olafur-eliasson-fait-son-numero-d-urgenceclimatique54998893246.html (accessed on 18 August 2019).

25. Passmore, J. Man's Responsibility for Nature; Duckworth: London, UK, 1974.

26. Pelt, M.J.F.v.; Kuyvenhoven, A.; Nijkamp, P. Project appraisal and sustainability: Methodological challenges. Proj. Apprais. 1990, 5, 139-158. [CrossRef]

27. Rasmussen, L.L. Energy: The Challenges to and from Religion. Zygon@ 2011, 46, 985-1002. [CrossRef]

28. Rowlands, M. Animal Rights: A Philosophical Defence; Macmillan: London, UK, 1998.

29. Scherer, D. Anthropcentrism, Atomism and Environmental Ethics. In Ethics and the Environment; Scherer, D., Attig, T.H., Eds.; Prentice-Hall: Englewood Cliffs, NJ, USA, 1983.

30. Shi, X. A Cultural Approach to Discourse; Palgrave Macmillan: New York, NY, USA, 2005.

31. Singer, P. Animal Liberation: A New Ethic for our Treatment of Animals; Jonathan Cape: London, UK, 1976.

32. Sterba, J. From Biocentric Individualism to Biocentric Pluralism. Environ. Ethics 1995, 17, 191-207. [CrossRef]

33. Warren, K. The Power and Promise of Ecological Feminism. Environ. Etheric 1990, 12, 121-146. [CrossRef]

34. Bell, S.; Morse, S. Experiences with Sustainability Indicators and Stakeholder Participation: A Case Study Relating to a Blue Plan Project. In Malta, International Sustainable Development Research; University of Manchester, ERP Environment: Manchester, UK, 2002.

35. Bossel, H. Assessing viability and sustainability: A systems-based approach for deriving comprehensive indicator sets. Conserv. Ecol. 2001, 5, 12. [CrossRef]

36. Gilbert, A. Criteria for sustainability in the development of indicators for sustainable development. Chemosphere 1996, 33, 1739-1748. [CrossRef]

37. Hak, T.; Moldan, B.; Dahl, A.L. Sustainability Indicators: A Scientific Assessment; Island Press: Washington DC, USA, 2007.

38. Howlett, M. Issue-attention and punctuated equilibria models reconsidered: An empirical examination of the dynamics of agenda-setting in Canada. Can. J. Political Sci./Rev. Can. Sci. Polit. 1997, 30, 3-29. [CrossRef]

39. Thompson, J.B. The Media and Modernity. A Social Theory of the Media; Cambridge University Press: Cambridge, UK, 1995.

40. Elliot, R. Faking Nature: The Ethics of Environmental Restoration; Routledge: London, UK; New York, NY, USA, 1997.

41. Glacken, C.J. Traces on the Rhodian Shore: Nature and Culture in Western Thought from Ancient Times to the End of the Eighteenth Century; University of California Press: Berkeley, CA, USA; London, UK, 1967.

42. Hargrove, E.C. Foundations of Environmental Ethics; Prentice-Hall: Englewood Cliffs, NJ, USA, 1989.

43. Jeffrey, P. Evolutionary analogues and sustainability: Putting a human face on survival. Futures. 1996, 28, 173-187. [CrossRef]

44. Jonas, H. The Imperative of Responsibility. In Search of an Ethics for the Technological Age; University of Chicago Press: Chicago, IL, USA; London, UK, 1984.

45. Kearns, L. Noah's Ark Goes to Washington: A Profile of Evangelical Environmentalism. Soc. Comp. 1997, 44, 349-366. [CrossRef]

46. Naisbitt, J. The Trend Report: A Quarterly Forecast and Evaluation of Business and Social Development; Center for Policy Process: Washington, DC, USA, 1976.

47. Plumwood, V. Nature, Self and Gender: Feminism, Environmental Philosophy, and the Critique of Rationalism. Hypatia 1991, 6, 3-27. [CrossRef]

48. Rolston, H., III. Science and Religion in the Face of the Environmental Crisis. In The Oxford Handbook of Religion and Ecology; The Oxford Handbook of Religion and Ecology; Gottlieb, R.S., Ed.; Oxford University Press: Oxford, UK, 2006; pp. 376-397.

49. Routley, R. Is There a Need for a New, an Environmental Ethics? In Proceedings of the Fifteenth World Congress of Philosophy; World Congress of Philosophy: Varna, Bulgaria, 1973; pp. 205-210.

50. Schaller, N. The concept of agricultural sustainability. Agric. Ecosys. Environ. 1993, 46, 89-97. [CrossRef]

51. Schley, S.; Laur, J. The sustainability challenge: Ecological and economic development. Sys. Think. 1996, 7, 1-6.

52. Stivers, R.L. The sustainable Society: Ethics and Economic Growth; Westminster Press: Louisville, KY, USA, 1976.

53. Stowell, F.A.; Ison, R.L.; Armson, R.; Holloway, J.; Jackson, S.; McRobb, S. (Eds.) Systems for Sustainability: People, Organizations and Environments; Plenum Press: New York, NY, USA; London, UK, 1997.

54. Taylor, P. Respect for Nature: A Theory of Environmental Ethics; Princeton University Press: Princeton, NJ, USA, 1986. 
55. Throop, W. Environmental Restoration: Ethics, Theory and Practice; Humanity Books: Amherst, MA, USA; New York, NY, USA, 2000.

56. Vivien, F.-D.; Dannequin, F.; Diemer, A.; Petit, R. La nature comme modèle? Écologie industrielle et développement durable. Ca. CERAS Nat. Cult. Econ. 2000, 38, 63-75.

57. Grim, J.; Tucker, M.E. Forum on Religion and Ecology at Yale. Available online: http://fore.yale.edu/about-us/ (accessed on 12 January 2020).

58. Christiansen, D. Church Teaching, Public Advocacy, and Environmental Action. Zygon® 2011, 46, 972-984. [CrossRef]

59. Clugston, R.; Holt, S. Exploring Synergies between Faith Values and Education for Sustainable Developmen; Earth Charter International: San José, CA, USA, 2012.

60. Gottlieb, R. You gonna be here long? Religion and Sustainability. World. Glob. Rel. Cult. Ecol. 2008, 12, 163-178. [CrossRef]

61. Kidd, C.V. The evolution of sustainability. J. Agric. Environ. Ethics 1992, 5, 1-26. [CrossRef]

62. Prades, J.A.; Tessier, R.; Vaillancourt, J.-G. Instituer le Développement Durable: Éthique de L'écodécision et Sociologie de L'environnement; Fides: Paris, France, 1994.

63. Kimmins, J.P. Ecology, environmentalism and green religion. For. Chron. 1993, 69, 285-289. [CrossRef]

64. Tucker, M.E. World Religions, the Earth Charter, and Sustainability. Worldviews Glob. Relig. Cult. Ecol. 2008, 12, 115-128. [CrossRef]

65. Bratosin, S.; Tudor, M.A. Religion(s), laïcité(s) et société(s) au tournant des humanités numériques; Iarsic: Les Arcs, France, 2016.

66. Bratosin, S.; Jauffret, M. Le mythe politique français de la laïcité: foi et sens politique. In Politique et religion au défi de la communication numérique; Tudor, M.A., Clitan, G., Grilo Marat, M., Eds.; l'Harmattan: Paris, France, 2018; pp. 41-55.

67. Tudor, M.A.; Bratosin, S. The Romanian Religious Media Landscape: Between Secularization and the Revitalization of Religion. J. Rel. Media Digit. Cult. 2018, 7, 223-250. [CrossRef]

68. Altheide, D.L. Media logic, social control, and fear. Commun. Theory 2013, 23, 223-238. [CrossRef]

69. Ampuja, M.; Koivisto, J.; Väliverronen, E. Strong and Weak Forms of Mediatization Theory. A Critical Review. Nord. Rev. 2014, 36, 111-123.

70. Asp, K. Medialization, media logic and mediarchy. Nord. Rev. 1990, 11, 47-50.

71. Bratosin, S.; Gomes, P.-D.; Neto, F.A. Mediatization of religion and power. Ess. J. Comm. Stud. 2017, 10, 5-203.

72. Bratosin, S. La médialisation du religieux dans la théorie du post néo-protestantisme. Soc. Comp. 2016, 63, 405-420. [CrossRef]

73. Couldry, N. Mediatization or mediation? Alternative understandings of the emergent space of digital storytelling. New Med. Soc. 2008, 10, 373-391. [CrossRef]

74. Couldry, N.; Hepp, A. Conceptualising Mediatization: Contexts, Traditions, Arguments. Commun. Theory 2013, 23, 191-202. [CrossRef]

75. Deacon, D.; Stanyer, J. Mediatization: Key concept or conceptual bandwagon? Media Cult. Soc. 2014, 36, 1032-1044. [CrossRef]

76. Gomes, P.G. Mediatization: A concept, multiple voices. ESSACHESS J. Commun. Stud. 2016, 9, $197-212$.

77. Gomes, P.G. A Midiatização no Processo Social; PPGcom: São Leopoldo, Brazil, 2017.

78. Hepp, A. Cultures of Mediatization; John Wiley \& Sons: Hoboken, NJ, USA, 2013.

79. Hjarvard, S.P. The Mediatization of Society. A Theory of the Media as Agents of Social and Cultural Change. Nord. Review. 2008, 29, 105-134.

80. Hjarvard, S.P. The Mediatization of Culture and Society; Routledge: London, UK; New York, NY, USA, 2013.

81. Kiousis, S. Explicating media salience: A factor analysis of New York Times issue coverage during the 2000 US presidential election. J. Commun. 2004, 54, 71-87. [CrossRef]

82. Krotz, F. Elektronisch mediatisierte kommunikation. Überlegungen Konzept. Einiger Zukünftiger Forsch. Kommun. Rundfunk Fernseh. 1995, 43, 445-462.

83. Krotz, F. Der Symbolische Interaktionismus und die Kommunikationsforschung Zum hoffnungsvollen Stand einer schwierigen Beziehung; Springer: Wiesbaden, Germany, 2001.

84. Krotz, F. Mediatisierung. Fallstud. zum Wan. von Komm; Springer VS: Wiesbaden, Germany, 2007.

85. Laurendeau, N.M. An Energy Primer: From Thermodynamics to Theology. Zygon® 2011, 46, 890-914. [CrossRef] 
86. Lövheim, M.; Lundmark, E. Gender, Religion and Authority in Digital Media. ESSACHESS-J. Commun. Stud. 2019, 12, 23-35.

87. Lundby, K. Mediatization: Concept, Changes, Consequences; Peter Lang: Bern, Switzerland, 2009.

88. Lundby, K. Mediatization of Communication; Walter de Gruyter GmbH \& Co KG: Berlin, Germany, 2014; Volume 21.

89. Lunt, P.; Livingstone, S. Is 'mediatization' the new paradigm for our field? A commentary on Deacon and Stanyer (2014, 2015) and Hepp, Hjarvard and Lundby (2015). Med. Cult. Soc. 2016, 38, 462-470. [CrossRef]

90. Tudor, M.A.; Bratosin, S. Croire en la technologie: Médiatisation du futur et futur de la médiatisation; Iarsic: Les Arcs, France, 2018.

91. Tudor, M.A. Multimédiatisation et événement religieux: le cas de la campagne d'évangélisation l'Horizon de l'espérance de Hope Channel Romania (Speranta TV). Tic et Soc. 2015, 9, 1-2. [CrossRef]

92. Krotz, F. Mediatization: A concept with which to grasp media and societal change. In Mediatization: Concept, Changes, Consequences; Lundby, K., Ed.; Peter Lang: New York, NY, USA, 2009; pp. 21-40.

93. Krotz, F. Explaining the Mediatisation Approach. Javn.-The Public 2017, 24, 103-118. [CrossRef]

94. Deuze, M. Media Life. Media Cult. Soc. 2011, 33, 137-148. [CrossRef]

95. Schulz, W. Reconstructing mediatization as an analytical concept. Eur. J. Commun. 2004, 19, 87-101. [CrossRef]

96. Blumer, H. What is wrong with social theory? Amer. Sociol. Rev. 1954, 18, 3-10. [CrossRef]

97. Evans, J.H. Faith in Science in Global Perspective: Implications for Transhumanism. Public Underst. Sci. 2014, 23, 814-832. [CrossRef] [PubMed]

98. Rothenbuhler, E.W.; Coman, M. Media Anthropology; Sage Publications: Thousand Oaks, CA, USA, 2005.

99. Stout, D.A. Media and Religion. Foundations of an Emerging Field; Routledge: New York, NY, USA; London, UK, 2012.

100. Debray, R. L'Emprise; Gallimard: Paris, France, 2000.

101. Rieder, B.; Röhle, T. Digital methods: Five challenges. In Understanding digital humanities; Berry, D.M., Ed.; Palgrave Macmillan: London, UK, 2012; pp. 67-84.

102. Fairclough, N. Discourse and Social Change; Polity Press: Cambridge, UK, 1992.

103. Fairclough, N. Language and Power; Pearson Education: Harlow, UK, 2001.

104. Bozorova, M. Coverage of the problem of human trafficking in the media: Content analysis of materials of editions of Russian Federation. ESSACHESS J. Commun. Stud. 2019, 12, 53-75.

105. Gallot, L. L'influence des médias sur la société. Available online: https://www.journaldunet.com/management/ expert/62682/l-influence-des-medias-sur-la-societe.shtml (accessed on 2 December 2019).

106. Fromages, E. L'horloge de l'apocalypse s'avance vers la fin $\mathrm{du}$ monde. Available online: https://www.sciencesetavenir.fr/nature-environnement/fin-du-monde-il-est-minuit-moins-deux-minutessur-1-horloge-de-l-apocalypse120217 (accessed on 2 December 2019).

107. UNDP. Sustainable Development Goals. Available online: https://www.undp.org/content/undp/fr/home/ sustainable-development-goals.html (accessed on 8 October 2019).

108. MAIF. Des produits de placements responsables. 2018. Available online: https://www.lemonde.fr/lepargne-solidaire/article/2018/11/08/des-produits-de-placementsresponsables53808865380848.html (accessed on 4 November 2019).

109. Vincent, A. Du Stella McCartney homme: Promesse d'une mode masculine éco-responsible. Available online: https://www.lefigaro.fr/mode-homme/2016/02/18/30007-20160218ARTFIG00213-du-stella-mccartneyhomme-promesse-d-une-mode-masculine-eco-responsable.php (accessed on 7 September 2019).

110. Peirce, C.S. Comment rendre nos idées claires. Rev. Philos. 1879, 7, 39-57.

111. Viau, M. Pragmatisme et théologie pratique. Rev. Théol. Philos. 1992, 124, 115-138.

112. Chauvet, A. Renoncer à faire des enfants pour la planète, l'étrange combat des femmes "ginks". Available online: https://www.20minutes.fr/planete/699029-20110401-planete-renoncer-faire-enfants-planete-etrangecombat-femmes-ginks (accessed on 17 December 2019).

113. Peyret, E.; Delmas, A.; Deborde, J. Alimentation: Sus au pourri gâché, Libération. 2018. Available online: https://www.liberation.fr/evenements-libe/2018/10/30/alimentation-sus-au-pourri-gache1688913 (accessed on 5 November 2019).

114. Moltmann, J. Dieu dans la création. In Traité Ecologique de la Creation; Cerf: Paris, France, 1988.

115. Suárez, M. Scientific Representation. Philos. Compass 2010, 5, 91-101. [CrossRef] 
116. Johnston, L.F. Religion and Sustainability: Social Movements and the Politics of the Environment; Routledge: London, UK; New York, NY, USA, 2014.

117. Holt, D.; Barkemeyer, R. Media coverage of sustainable development issues - attention cycles or punctuated equilibrium? Sustain. Dev. 2012, 20,1-17. [CrossRef]

118. Camus, S.; Poulain, M. La spiritualité: Émergence d'une tendance dans la consommation. Manag. Avenir 2008, 5, 72-90. [CrossRef]

119. Champion, F. Thérapies et nouvelles spiritualités. Sci. Hum. 2000, 106, 32-35.

120. Beyer, P. Sensing Religion, Observing Religion, Reconstructing Religion: Contingency and Pluralization in Post-Westphalian Context. Soc. Comp. 2016, 63, 234-250. [CrossRef]

121. Rieffel, R. Journalistes et intellectuels: Une nouvelle configuration culturelle? Réseaux Commun. Technol. Société 1992, 51, 11-24. [CrossRef]

122. Meyrowitz, J. Understandings of media. ETC Rev. Gen. Semant. 1999, 56, 44-52.

(C) 2020 by the authors. Licensee MDPI, Basel, Switzerland. This article is an open access article distributed under the terms and conditions of the Creative Commons Attribution (CC BY) license (http://creativecommons.org/licenses/by/4.0/). 